- осуществление дальнейшего совершенствования нормативной правовой базы в сфере организации и проведения воспитательной работы среди сотрудников органов внутренних дел.

Таким образом, подводя итог вышесказанному, можно констатировать следующее:

1) исследование вопросов, посвященных особенностям организации и проведения воспитательной работы среди личного состава органов внутренних дел, имеет существенное значение с точки зрения систематизации административно-правовых и психологопедагогических знаний в данной области;

2) воспитательная работа является основным видом моральнопсихологического обеспечения деятельности органов внутренних дел;

3) мы полагаем, что вопросы, связанные с институтом воспитательной работы в органах внутренних дел, нуждаются в дальнейшем комплексном рассмотрении и анализе с позиции постоянного совершенствования практической деятельности в указанной сфере.

$$
* * *
$$

1. Конституция Российской Федерации: Принята всенародным голосованием 12 декабря 1993 года // Российская газета, 1993, 25 декабря.

2. Послание Президента Российской Федерации Федеральному Собранию Российской Федерации от 15 января 2020 года // Российская газета, 2020, 16 января.

3. Порядок организации морально-психологического обеспечения деятельности органов внутренних дел Российской Федерации: утвержден Приказом МВД России от 25 декабря 2020 года № 900.

4. Бялт В. С., Трипутин С. Н. Актуальные проблемы профессионально-нравственного воспитания в образовательных организациях системы МВД России // Вестник Санкт-Петербургского университета МВД России. 2014. № 2 (62). С. 196-200.

5. Воробьев И. Ю. Инновационные педагогические технологии профессионального воспитания сотрудников органов внутренних дел: Дисс. ... канд. педаг. наук. - М., 2019.

6. Деккерт Д. В. Воспитание патриотизма как компонента профессионально-нравственной культуры сотрудников органов внутренних дел // Вестник Барнаульского юридического института МВД России. 2019. № 2 (37). С. 153-156.

7. Мазаник Е. Н. О роли информационно-пропагандистской работы в правовом воспитании сотрудников органов внутренних дел // Актуальные проблемы права и государства в XXI веке. 2019. T. 11. № 1. C. 70-74.

8. Панферкина И. С. Антикоррупционное воспитание и его роль в профессионально-нравственном воспитании сотрудников органов внутренних дел // Общественная безопасность, законность и правопорядок в ІІІ тысячелетии. 2019. № 5 3. С. 58-60.

\title{
Вельдина Ю.В. \\ Международная программа обмена как средство изучения языка и культуры Германии
}

Пензенский государственный технологический университет (Россия, Пенза)

doi: $10.18411 / l j-02-2021-126$

idsp: ljournal-02-2021-126

\section{Аннотация}

В данной статье автором рассматривается международная программа обмена как одним из эффективных методом изучения немецкого языка. Погружение в среду изучаемого языка и общение с носителями данного языка помогает не только улучшить знания в грамматике, фонетике, лексике, но и узнать многое о культуре народа, его обычаях, традициях, истории. Кроме того, программа обмена помогает избавиться от стереотипов, которые мешают межкультурной коммуникации, а, следовательно, и овладению языком. 
Ключевые слова: международная программа обмена, метод, немецкий язык, Германия.

\section{Abstract}

The article deals with the international program as one of the effective teaching methods of learning German. Immersion in the environment of the studied language and communication with native speakers helps not only to improve knowledge in grammar, phonetics, vocabulary, but also to learn more about the culture of the people, their customs, traditions, and history. Also, the international program helps to get rid of stereotypes that hamper intercultural communication and therefore language acquisition.

Keywords: the international program, teaching method, German, Germany.

В настоящее время все больше людей стремится к изучению иностранных языков. Многие изучают английский, немецкий, французский, китайский или любой другой язык для того, чтобы коммуницировать с иноязычными родственниками, друзьями, партнерами по бизнесу, коллегами по работе и т. д. Но помимо изучения языка для общения многие изучают его для понимание технологий, инструкций и получения информации, которая не доступна человеку на его родном языке.

Немецкий язык занимает 2-е место среди изучаемых языков в России. Согласно исследованиям, ВЦИОМ от 30 сентября 2019 года по сравнению с предыдущими годами все больше россиян признают преимущества в изучении иностранных языков. Несомненно, на изучение языка влияют и мировые тенденции. В связи с этим наибольшее предпочтение отдано изучению английского языка (93\% респондентов), на втором месте китайский - 43\%, на третьем немецкий язык - 32\%. Большинство опрошенных россияне применяют иностранные языки для чтения зарубежной литературы, инструкций, сайтов. Также многие используют знание языка для профессиональной деятельности и поездок за границу [1].

А где же россияне изучают иностранный язык? По данным опроса, 20\% изучают самостоятельно с применением самоучителей и пособий, программы и интернет курсы, $19 \%$ обращаются в языковые школы, общаются с носителями языка $18 \%, 15 \%$ изучали или изучают иностранные языки в университете на дополнительных курсах, 14\% занимаются с репетитором, $12 \%$ россиян поднимали уровень владения иностранным языком, просматривая зарубежные фильмы и всего лишь 7\% опрошенных проходили языковую практику за границей [1].

Однако, оценка зарубежных специалистов неутешительна. Знание иностранного языка россиянами находится на низком уровне в сравнении с другими странами. Следовательно, чтобы повысить качество изучения иностранного языка, а в частности немецкого языка нужно уделить больше внимания обучению россиян от школьников до взрослого населения, стремящегося изучать немецкий язык.

Важность изучения немецкого языка высока, только в странах Европы огромное количество населения говорящего на немецком языке. Помимо Германии - это Австрия, Швейцария, Лихтенштейн, Люксембург, северная Италия, восточная Бельгия и др. Германия является одной из крупнейших промышленных стран, у неё богатое культурное наследие, также немцы активно развивают программы обмена [2].

Программа обмена способствует культурному, технологическому, промышленному, экономическому развитию, как самой Германии, так и странам, участвующим в этой программе. Обмен продвигает процесс глобализации вперед, это происходит по тому, что общаются между собой люди с разных концов земли. Они изучают языки друг друга, что облегчает дальнейшее сотрудничество. Изучение немецкого языка имеет множество трудностей, к которым можно отнести следующие: грамматика, артикли, лексика, произношение и т. д. Но главная трудность в изучении 
иностранного языка - это живое общение, когда «на практике» приходится применять все ранее полученные языковые знания.

Обмен - школьный, студенческий или профессиональный - это эффективный метод позволяющий изучать немецкий язык. В связи с этим, программа обмена - это взаимопроникновение культур, установление дружеских отношений, расширение кругозора, формирование новых взглядов на мир, познание самого себя, также погружение в среду изучаемого языка и непосредственное повседневное общение с его носителями. Это помогает улучшить знания в грамматике, фонетике, обогатить лексический запас и узнать новое о культуре народа Германии, их обычаях, истории, традициях, которые связаны с самим языком. Также обмен способствует избавлению от стереотипов, которые мешают международной коммуникации и сближению наций. Большим плюсом является то, что при обмене, у школьников или студентов из России в процессе изучения немецкого языка появляются новые друзья и приобретаются навыками общения с другими национальностями без культурного и языкового барьера [3].

В настоящее время мобильность и гибкость в обучении рассматриваются как необходимые качества молодых специалистов и школьников. Ничто так не может активизировать познавательную деятельность, привнести новый опыт, расширить мировоззрение, мотивировать изучать иную культуру и язык, как непосредственное погружение человека в иную, иностранную обстановку, пребывание в другой стране, общение со сверстниками, что и входит в программу по обмену.

Для школьников программа обмена - это хорошая возможность заложить крепкий фундамент в изучении немецкого языка, получить опыт общения со сверстниками другой культуры, участвовать в повседневных делах немецкой семьи, что качественно способствует изучению культуры Германии изнутри. Программа обмена позволяет школьникам определиться с дальнейшими целями по изучению языка и помогает им в выборе профессий, напрямую или косвенно связанных с немецким языком и немецкой культурой.

Для студентов программа обмена - это, в первую очередь, отличная возможность изучить немецкий язык в специализированной, профессиональной среде, возможность получить необходимые практические навыки и умения в разговорном немецком языке. Также студенческий обмен позволяет погрузиться в производственную среду Германии, изучить профессиональные особенности и методики другой страны, осуществлять работу на зарубежном оборудовании, осваивать новые знания о своей профессии. Студенты ставят новые цели в своем профессиональном будущем, а программа обмена способствует их осуществлению.

Для людей, работающих в той или иной сфере деятельности, программа обмена - это возможность поднять уровень владения немецким языком в более узкой профессиональной сфере. Также в программу обмена может входить повышения квалификации или обучение специалистов для работы на немецком оборудовании в России. Специалисты осваивают новые профессиональные горизонты, будь то углубление знаний или же получение смежной специальности. Все это способствует их качественному профессиональному карьерному росту [3].

В Германии существует множество программ обмена, но наиболее распространённая - это студенческая программа по обмену. Данная программа дает возможность молодым специалистам в течение 6-12 месяцев обучаться, проходить практику на территории Германии. Обмен может предполагать обучение ряду дисциплин, но при этом студенты могут обогатить свое образование через немецкий язык и культурный опыт.

Немецкая программа обмена - это многогранные занятия позволяющие получить практический профессиональный опыт, студент получает необходимые навыки для написания курсовых и дипломных работ. Помимо непосредственного 
обучения студенты расширяют горизонт, приобретают новые навыки и знакомства, изучая, при этом немецкий язык и, совершенствуя свои навыки и умения. Программа обмена предлагает студентам посмотреть на окружающий мир другими глазами, достичь понимания, открытости, повысить свой интерес к другим культурам, избавиться от предвзятого мнения и развить коммуникативные способности [4].

Таким образом, проанализировав статистические данные и информацию о заявленной статье теме исследования, можно сделать выводы о том, что изучение иностранного языка, в частности немецкого, с каждым годом становится популярнее, но методы его изучения в России при этом требуют модернизации. Программа обмена является одним из способов изучения немецкого языка и имеет ряд преимуществ по сравнению с другими методами изучения такие как: погружение в языковую культуру, познание тонкостей немецкого языка, получение иного опыта, ознакомление с историей и культурой другой страны и др.

$$
* * *
$$

1. Всероссийский центр исследования общественного мнения ВЦИОМ [Электронный ресурc] URL: https://wciom.ru

2. Электронная энциклопедия [Электронный ресурc] URL: https://ru.wikipedia.org

3. Информационный общедоступный ресурс [Электронный ресурc] URL: https://www.deutschland.de

4. Информационный ресурс образование за рубежом [Электронный ресурc] URL: https://staracademy.ru

\section{Ворожейкин С.Б. ${ }^{1}$, Бадмаева А.Б. ${ }^{2}$ \\ Единство процессов составления и решения задач на коэффициент растворимости \\ ${ }^{1}$ ФГБОУ ВО «Калмыцкий государственный университет имени Б. Б. \\ Городовикова» \\ ${ }^{2}$ МБОУ «Элистинская многопрофильная гимназия» (Россия, Элиста)}

doi: $10.18411 / l j-02-2021-127$

idsp: ljournal-02-2021-127

\section{Аннотация}

Одним из взаимосвязанных подходов к обучению, рассматриваемые в публикации, является обеспечение единства процессов составления и решения задач. Составление и решение обратной задачи выступает простым и удобным критерием развития творческого мышления обучающихся - она «всегда приводит ученика к постановке новых проблем» (П.М. Эрдниев).

Укрупненная дидактическая единица обладает качествами системности и целостности, устойчивостью к сохранению во времени и быстрым проявлением в памяти. Особую актуальность УДЕ приобретает в условиях введения ФГОС. Принципы технологии УДЕ способствуют формированию универсальных учебных действий, ключевых метапредметных компетенций, развитию учебно-познавательных возможностей обучающихся.

Матрица-обращение позволяет моделировать условия и определить неизвестный вопрос для обратных задач (Б. П. Эрдниев). От числа физических параметров прямой расчетной задачи в основном зависит и число обратных задач. В отличие от общепринятой записи условий задач предлагается строчная запись, внесенная в матрицу. Непременным условием решения обратных задач является составление текста задачи. Совокупность прямой и обратной задач приводит к достижению системности знаний по химии. Главная особенность укрупнения единицы усвоения - создание условий для постижения богатства связей и переходов между компонентами единого знания. 